\title{
Analysis of vanillin by TLC and HPLC-PDA in herbal material and tincture from Vanilla planifolia Jacks ex. Andrews
}

\author{
Magda Rhayanny Assunção Ferreira, ${ }^{\mathrm{a}, \mathrm{b}}$, Melissa Schwanz $^{\mathrm{c}}$, Gustavo Pereira Cosenza ${ }^{\mathrm{d}}$, \\ Amélia Teresinha Henriques ${ }^{\mathrm{c}}$, Luiz Alberto Lira Soares ${ }^{\mathrm{a}, \mathrm{b}^{*}}$ \\ ${ }^{a}$ Laboratório de Farmacognosia, Departamento de Ciências Farmacêuticas, Universidade Federal de Pernambuco, Av. Prof. \\ Arthur de Sá, s/n, Cidade Universitária, 50740-521, Recife-PE, Brazil. \\ ${ }^{b}$ Programa de Pós-graduação em Ciências Farmacêuticas, Universidade Federal de Pernambuco, Av. da Engenharia, s/n, 2. \\ Andar, Cidade Universitária, 50740-600, Recife - PE, Brazil. \\ ${ }^{c}$ Laboratório de Farmacognosia e Controle de Qualidade Farmacêutica, Faculdade de Farmácia, Universidade Federal do Rio \\ Grande do Sul - UFRGS, Av. Ipiranga, 2752, 90610-000, Porto Alegre/RS, Brazil \\ ${ }^{d}$ Faculdade de Farmácia da UFMG, Universidade Federal de Minas Gerais, Avenida Antonio Carlos Pampulha, 31270-901 -
} Belo Horizonte, $M G$ - Brazil

*Corresponding author: phtech@uol.com.br

Vanilla planifolia (Orchidiaceae) is a species that is renowned globally and represents the largest source of vanillin flavoring used in the food, cosmetic and pharmaceutical industries. This study was carried out to analyze by TLC and HPLC-PDA vanillin in herbal material and tincture from $V$. planifolia. The herbal material was obtained with hydroalcoholic solution under reflux; and a kinetic reaction was performed by TLC. The influences of solvent and herbal material concentration were studied through an experimental design. The solutions (herbal material, tincture and standard - vanillin) were prepared and analyzed in HPLC coupled with DAD detector, using wavelength of $280 \mathrm{~nm}$. The total extraction of vanillin was achieved after three extraction cycles, using $1.0 \mathrm{~g}$ of herbal material and Ethanol $50 \%(\mathrm{v} / \mathrm{v})$ as solvent. The method was linear $\left(R^{2}>0.99\right)$ and demonstrated repeatability ( $\mathrm{RSD}<0.90)$, intermediate precision ( $\mathrm{RSD}<1.09$ ), recovery $(93.12-113.74 \%$ ), as well as robustness $(\mathrm{RSD}<4.33)$. The total content of vanillin found was $1.82 \mathrm{~g} \%$ and $0.21 \mathrm{~g} \%$ for herbal material and tincture, respectively. A simple and optimized method for sample preparation by reflux was able to provide the exhaustive extraction of vanillin and does not compromise the reliability of the HPLC-PDA method. The chromatographic procedure was validated to separate and quantify vanillin in herbal material and tincture from pods of $V$. planifolia.

Keywords: Vanilla planifolia; Vanillin; High Performance Liquid Chromatography; Thin Layer Chromatography; Experimental Design.

\section{Introduction}

Vanilla planifolia Jacks. ex Andrews (Orchidiaceae), also known as Notylia planifolia (Andrews) Conz and is popularly known in Brazil as "baunilha" (1). It is a specie that is renowned worldwide for its "aroma of vanillin" produced by the pods, the only comestible member of this botany family (2-5). The plant is native to Central America and South America, occurring in tropical and subtropical areas (6).

In its chemical composition, the species shows some phenolic compounds, such as p-hydroxybenzoic acid and vanillic acid. However, the main compound present in vanilla, is vanillin (4-hydroxy-3-methoxybenzaldehyde), which is used worldwide as a flavoring agent in the food, cosmetic and pharmaceutical industries (7-10).

In regard to the commercial relevance of vanillin, quantitative analysis plays an important role in the standardization of herbal material and extractives obtained from the Vanilla planifolia species. Several analytical tools have been used to perform the quality control of vanilla extractives such as thin layer chromatography - TLC (11), high performance thin layer chromatography - HPTLC (12), gas chromatography - GC (13), solid-phase micro- extraction followed by GC (14), micellar electrokinetic chromatography (15) and high performance liquid chromatography - HPLC $(16,17)$.

Despite extensive studies with HPLC due to its sensitivity and accuracy, the literature reports certain analytical approaches focused either on drug material or derived product from $V$. planifolia. Thus, this paper describes the resulting optimization study by TLC, and the experimental design and validation of a high performance liquid chromatography coupled with photodiode array detector (HPLC-PDA) method for determination of vanillin in herbal material and tincture obtained from $V$. planifolia.

\section{Experimental}

\section{Chemicals and materials}

Reference substance Vanillin (98\% purity) was purchased from Vetec $^{\circledR}$. Methanol was HPLC grade (J.T. Baker ${ }^{\circledR}$, USA), purified water was used (PURELAB ${ }^{\circledR}$ Classic UV, ELGA LabWater, USA) and glacial acetic acid $\left(\right.$ Vetec $\left.^{\circledR}\right)$. Ethanol (Analytical grade, Cinética ${ }^{\circledR}$ ) and distilled water to obtain the tincture were also used. The vanilla pods (Vanilla planifolia) were purchased from Germany (Kräutergarten 
Drug Anal Res, 2018; 02, 1-7

München, 2012). Pods were obtained dried, then powdered and maintained in a desiccator at room temperature $\left(24^{\circ} \mathrm{C}\right)$.

\section{Preparation of vanilla tincture}

The tincture was prepared by percolation of the grounded herbal material using ethanol $70 \%(\mathrm{v} / \mathrm{v})$ as extractor solvent, at a drug: solvent ratio of 1:10 (18).

\section{General procedure for herbal material}

The sample of herbal material was transferred to a roundbottom flask of $250 \mathrm{~mL}$ and added to $30.0 \mathrm{~mL}$ of hydroalcoholic solution $(50 \%, \mathrm{v} / \mathrm{v})$. The mixture was heated up in a water bath, under reflux, for $30 \mathrm{~min}$. Subsequently, the extract was cooled to room temperature $\left(25^{\circ} \mathrm{C}\right)$, filtered through cotton into a volumetric flask of $100 \mathrm{~mL}$ and the residue (cotton and herbal material) was re-extracted twice using $30.0 \mathrm{~mL}$ of hydroalcoholic solution for $15 \mathrm{~min}$. The volume was completed to $100 \mathrm{~mL}$ originating the stock solution (SS).

\section{Kinetics of extraction by TLC}

The sample was prepared as described above and the extraction kinetics were evaluated by TLC analysis of collected fractions $(100 \mu \mathrm{L})$ from the extraction medium, for $15 \mathrm{~min}$ each until reaching $120 \mathrm{~min}$. The extraction performance was confirmed by a second series of experiments using the following time intervals: $0,30,45$ and 60 minutes. Aliquots of $10 \mu \mathrm{L}$ from each collected fraction or standard solution (vanillin $1.0 \mathrm{mg} / \mathrm{mL}$ in methanol) were applied at $5 \mathrm{~mm}$ band width, in tracks on precoated TLC silica gel $60 \mathrm{~F}_{254}$ aluminum plates $(20 \times 10 \mathrm{~cm} ; 250 \mu \mathrm{m}$ thickness; $\quad$ Macherey-Nagel $^{\circledR}$, Germany). The chromatograms were developed in a twin trough vertical glass chamber $\left(20 \times 10 \mathrm{~cm}\right.$; Camag ${ }^{\circledR}$, Switzerland $)$ using anhydrous acetic acid: methanol: methylene chloride $(0.5: 1: 98.5, \mathrm{v} / \mathrm{v} / \mathrm{v})$ as mobile phase. The optimized chamber saturation time for the mobile phase was $30 \mathrm{~min}$ at room temperature $\left(25 \pm 2{ }^{\circ} \mathrm{C}\right)$. After development, the plate was dried and the components were visualized by UV irradiation at $254 \mathrm{~nm}$. Each analysis was carried out in duplicate.

\section{Optimization of drug extraction}

The influences of solvent and amount of herbal material on extraction performance were studied through an experimental design $2^{2}$ added to 3 central points (19). Each point represents an average of three determinations. The results were adjusted by Partial Least Squares (PLS) to a mathematical model, which was evaluated statistically and used to generate the response surface. The independent variables for experimental design were the solvent concentration and herbal material amount. The dependent variable (response) was the peak area (mUA) of vanillin. In order to compare the effects of factors, their natural values of independent variables were coded (Table 1). A second order model was established for the responses by PLS and its validation was performed through analysis of variance, multiple-correlation coefficients, and estimation of the lack of fit using STATISTICA6.0 (Statsoft ${ }^{\circledR}$, USA) (19).

Table 1 Matrix of Experimental Design applied to evaluate the influence of drug amount $(\mathrm{g})$ and solvent concentration $(\%)$ on the method response (Area)

\begin{tabular}{l|cc|ccc}
\hline & \multicolumn{2}{|c|}{$\begin{array}{c}\text { Coded } \\
\text { Variables }\end{array}$} & \multicolumn{2}{c|}{$\begin{array}{c}\text { Natural } \\
\text { variables }\end{array}$} & $\begin{array}{c}\text { Method } \\
\text { Response }\end{array}$ \\
\hline $\begin{array}{l}\text { Experimen } \\
\mathbf{t}\end{array}$ & $\begin{array}{c}\text { Dru } \\
\mathbf{g}(\mathbf{g})\end{array}$ & $\begin{array}{c}\text { Solven } \\
\mathbf{t}(\mathbf{\%})\end{array}$ & $\begin{array}{c}\text { Dru } \\
\mathbf{g}(\mathbf{g})\end{array}$ & $\begin{array}{c}\text { Solven } \\
\mathbf{t}(\mathbf{\%})\end{array}$ & $\begin{array}{c}\text { Area } \\
(\mathbf{m A U})\end{array}$ \\
\hline 1 & -1 & -1 & 0.5 & 50 & 22.966 \\
2 & -1 & 0 & 0.5 & 70 & 22.943 \\
3 & -1 & 1 & 0.5 & 90 & 22.835 \\
4 & 0 & -1 & 1.0 & 50 & 48.432 \\
5 & 0 & 0 & 1.0 & 70 & 42.486 \\
6 & 0 & 1 & 1.0 & 90 & 44.857 \\
7 & 1 & -1 & 1.5 & 50 & 73.001 \\
8 & 1 & 0 & 1.5 & 70 & 65.072 \\
9 & 1 & 1 & 1.5 & 90 & 67.207 \\
10 & 0 & 0 & 1.5 & 50 & 43.119 \\
\hline 11 & 0 & 0 & 1.5 & 70 & 43.543 \\
\hline
\end{tabular}

\section{HPLC-PDA Analysis}

The quantitative analyses were performed with High Performance Liquid Chromatography (Ultimate 3000, ThermoScientific ${ }^{\circledR}$ ) equipped with photodiode array detector (PDA), automatic pump, degasser and loop $20 \mu \mathrm{L}$. The system was controlled by Chromeleon ${ }^{\circledR}$ version 6 (Dionex, Thermo Fisher Scientific $\left.{ }^{\circledR}\right)$. The chromatographic separation was performed using a column of $150 \mathrm{~mm}$ length and 4.6 $\mathrm{mm}$ internal diameter $\left(\mathrm{C}_{18}, 5 \mu \mathrm{m}\right.$; Macherey-Nagel $\left.{ }^{\circledR}\right)$ and a $\mathrm{C}_{18}$ guard cartridge system $\left(4 \mu \mathrm{m}, 4.6 \mathrm{~mm} \times 20 \mathrm{~mm} ; \mathrm{C}_{18}, 5\right.$ $\mu \mathrm{m}$ Macherey-Nagel ${ }^{\circledR}$ ). The analysis was performed at room temperature $\left(24 \pm 2{ }^{\circ} \mathrm{C}\right)$. The mobile phase consisted of water (A) and methanol (B), both acidified with $0.5 \%$ glacial acetic acid, flow $1.0 \mathrm{~mL} / \mathrm{min}$, gradient mode $(0-10$ min: $10-30 \% \mathrm{~B}$; $10-17$ min: $30-80 \% \mathrm{~B} ; 17-17,5 \mathrm{~min}: 80 \% \mathrm{~B}$; 17,5-18 min: $80-10 \% \mathrm{~B}$ ) and previously degassed using an ultrasonic bath (Ultracleaner ${ }^{\circledR}$ ).

\section{Wavelength selection, Specificity and Identification of the peak}

The wavelength for determination of peaks was performed by scanning the standard, vanillin, in the range from $190 \mathrm{~nm}$ to $400 \mathrm{~nm}$. The analysis of the spectrum was used to confirm the identity of each compound of interest. Additionally, scans from $190 \mathrm{~nm}$ to $400 \mathrm{~nm}$ were performed for the extract solution from the herbal material, tincture and for the spiked extractive solution and tincture with the standard (vanillin) in order to verify the occurrence of deviation from the maximum wavelength. Therefore, the peak in the samples were identified by comparing their retention time and area with the standard.

\section{HPLC-PDA method development and validation}

For validation of analytical method developed, the guidelines of ICH (International Conference on the Harmonization of Technical Requirements for the 
Drug Anal Res, 2018; 02, 1-7

Registration of Pharmaceuticals for Human Use) (20) were used along with the Brazilian regulation RDC 166/2017 employed by National Health Surveillance Agency (ANVISA) (21).

\section{System suitability}

According with Food and Drug Administration (FDA), the standard solution of vanillin was considered for system suitability determination, where a minimum resolution (Rs) of analyte peak from closet peak $>2$; precision/injection repeatability $(\mathrm{RSD}) \leq 1$ with number onf samples $\geq 5$; capacity factor $\left(k^{\prime}\right)>2$; tailing factor $(T) \leq 2$ and number of theorical plates $(\mathrm{N})>2000$ (22).

\section{Specificity}

The specificity was determined by analysis of chromatograms of vanillin and the solutions of herbal material and tincture from $V$. planifolia. The PDA-detector in association with the software resource provided by the workstation and co-elution of the standard and the extracts were employed to confirm the purity across the peak at a retention time corresponding to that of vanillin.

\section{Calibration curve of the standard}

The linearity was determined by calibration curves of the standard solution (vanillin), herbal material and tincture of $V$. planifolia. Regarding the curve of the standard, $50.0 \mathrm{mg}$ of vanillin was dissolved in a $50.0 \mathrm{~mL}$ volumetric flask with methanol $(1.0 \mathrm{mg} / \mathrm{mL})$. The standard solution was used to prepare the calibration curve containing five points each and ranged from 32.0 to $48.0 \mathrm{mg} / \mathrm{mL}$. The samples curves (herbal material and tincture) were prepared with a concentration of between 1600 and $2400 \mu \mathrm{g} / \mathrm{mL}$. All solutions were filtered through nylon membrane $(0.45 \mu \mathrm{m}$, $13 \mathrm{~mm}$, FilterPro $\left.{ }^{\circledR}\right)$ before injection and each concentration point was performed in triplicate. The data were evaluated by the slope; the intercept with respective confidence intervals; and the coefficient of determination $\left(R^{2}\right)$. The calculations and statistical evaluation were carried out by linear regression and Analysis of Variance (ANOVA).

\section{Limits of detection (LOD) and quantification (LOQ)}

The limit of detection (LOD) and limits of quantification (LOQ) were calculated based on the standard deviation (S) of the intercept with axis $\mathrm{Y}$ and the slope of the calibration curve (I). LOD was calculated according to the expression $3.3 \times \mathrm{S} / \mathrm{I}$ and LOQ was established by using the expression $10 \times \mathrm{S} / \mathrm{I}$.

\section{Precision}

The precision of the method was evaluated at three levels: repeatability and intermediate precision. The standard deviation (SD) and relative standard deviation (RSD\%) were calculated by the injection of six independent samples at test concentration of $100 \%$ to the level of repeatability; and in the intermediary precision was calculated from three independent samples at test concentration of $100 \%$, analyzed by two operators on two different days (for the herbal material and the tincture).

\section{Accuracy}

The accuracy was determined through recovery analysis. Samples of the herbal material and tincture were added to known amounts of vanillin in the following concentrations: 80,100 and $120 \%$ of the analysis concentration. The experiments were performed in triplicate and the percentage of recovery substance was determined by dividing the actual concentration obtained by the experimental concentration using the calibration curve of the standard and multiplied by $100 \%$.

\section{Robustness}

The robustness of both methods were evaluated by performing minor modifications to the methodology, monitoring retention time (Rt) and vanillin content, such as: flow rate of mobile phase $(0.900 \mathrm{~mL} / \mathrm{min}$ and 1.100 $\mathrm{mL} / \mathrm{min}) ; \mathrm{pH}$ of the mobile phase $(\mathrm{pH} 2.0$ phase $\mathrm{A}$ and phase B 3.0, pH 3.0 phase A and phase B 4.0); and column oven temperature $\left(23{ }^{\circ} \mathrm{C}\right.$ and $\left.25^{\circ} \mathrm{C}\right)$.

\section{Quantification of vanillin}

The concentrations of vanillin in herbal material and tincture were obtained using the calibration curves of vanillin.

\section{Results and discussion}

The exhaustive extraction of vanillin from $V$. planifolia pods plays an important role due to the economic interest in the natural resource of this substance. Thus, extraction procedures and conditions have been tested to improve the extraction yield with a lower cost and shorter time. Certain approaches are reported in the literature, examples being modified traditional methods (mixtures of solvents, fraction enrichment and time of extraction); or assisted extraction by using ultrasound, microwave or pressure (23). Due to the inherent advantages of assisted methods, they are promising strategies for large-scale production of vanillin (24). Regarding the preparation of analytical samples, the optimized conventional methods can offer a simple and efficient validity method.

The chromatogram obtained from the herbal material was observed under ultraviolet light and four bands with blue/violet color could be observed, with one of them showing the same position obtained from the standard solution $\left(\mathrm{R}_{\mathrm{t}} \sim 0.9\right)$. Moreover, the chromatogram data enabled us to note that the spot corresponding to the vanillin achieved maximum intensity after $30 \mathrm{~min}$ of extraction, suggesting that this corresponds to the range in which the extraction of this metabolite occurs. After $45 \mathrm{~min}$, a significant reduction in the intensity of the spots was observed, corresponding to the pattern including vanillin. 
Subsequently, the exhaustion of herbal material occurs, with the disappearance of the chromatographic bands. The data revealed that the time required for the extraction of vanillin and complete exhaustion of the herbal material was reached after $50 \mathrm{~min}$. Thus, the realization of the extraction cycle with an initial extraction of $30 \mathrm{~min}$ and then $15 \mathrm{~min} 2 \mathrm{x}$ more provided assurance of the procedure of herbal material preparation for analytical tests for the quality control of $V$. planifolia (Figure 1).
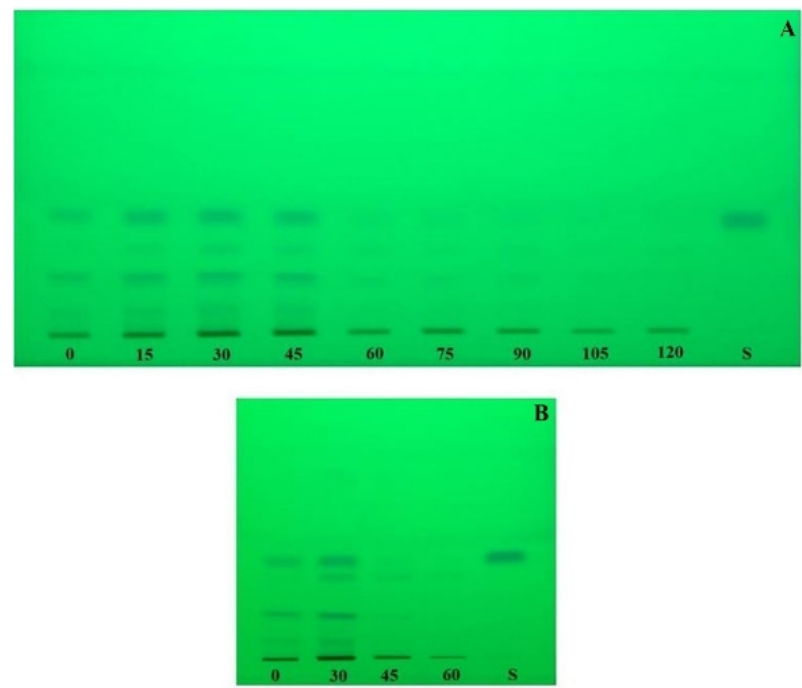

Figure 1 The chromatographic analysis by TLC of the extraction of herbal material from pods of $V$. planifolia.

\section{Optimization of drug extraction parameters}

The results for method performance with herbal material and solvent concentration are shown in Table 1 . The experimental data is used to generate second-order models for each dependent variable. The lack-of-fit test was not significant. The mathematical model to be used to explain the surface and the data used to generate the response surface is seen in Figure 2.

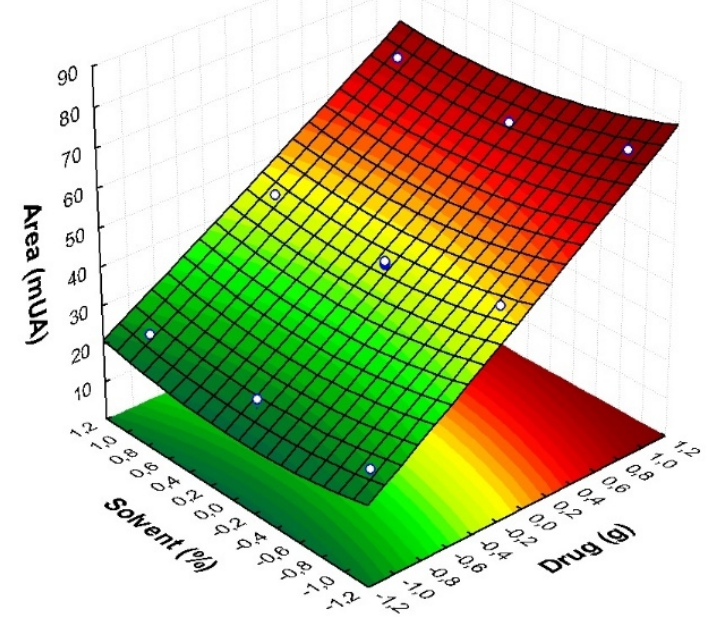

Figure 2 Effects of drug and solvent concentration on the chromatographic responses for the analytical methodology applied to herbal material from pods of $V$. planifolia.
The statistical analysis of the experimental design is summarized in table 2 . The $F$-test showed significant influence for both factors (drug amount and solvent concentration), demonstrating that they play an important role on the studied response. Moreover, the $t$-test for the coefficients showed the statistical importance of both linear terms, but the drug amount was the main factor and improves the analytical response (Figure 2). The contributions of second-orders terms are understood as the presence of curvature and describe the major behavior of the solvent concentration.

Table 2 Summary of the statistical analysis for the experimental design applied to evaluate the influence of the factors (drug amount and solvent concentration) on the method responses for herbal material (pods) of $V$. planifolia.

\begin{tabular}{lcc}
\hline \multicolumn{1}{c}{ Source } & $\begin{array}{c}\boldsymbol{F} \\
\text { (factor) }\end{array}$ & $\begin{array}{c}\boldsymbol{t} \text {-value } \\
\text { (coefficients) }\end{array}$ \\
\hline Drug (g) (Linear) & $10980.69^{*}$ & $104.789^{*}$ \\
\hline Drug (g) (Quadratic) & 1.29 & -1.134 \\
\hline Solvent (\%) (Linear) & $53.16^{*}$ & $-7.913^{*}$ \\
\hline $\begin{array}{l}\text { Solvent (\%) } \\
\text { (Quadratic) }\end{array}$ & $81.45^{*}$ & $-9.025^{*}$ \\
\hline $\begin{array}{l}\text { Interaction (Drug vs } \\
\text { Solvent) }\end{array}$ & $28.33^{*}$ & $-5.323^{*}$ \\
\hline \multicolumn{1}{c}{ Lack of Fit } & 11.16 & - \\
\hline *Significant for $\alpha=0.05$ &
\end{tabular}

\section{Method development}

In this study, the mobile phase, column chromatography and other conditions were the same employed throughout the process. Initially, various mobile phases were tested in order to establish the optimum condition for analysis of the herbal material and tincture of $V$. planifolia. Several studies report the use of different mobile phases by modifying only the aqueous phase: using a $1 \%$ phosphoric acid (23), or acetic acid $0.2 \mathrm{M}(24), 0.05 \%(25), 1.25 \%$ (26), and the ratio of water: acid acetic - 99.8:0.2 (16). Some of these studies report the use of organic mobile phase consisting of a mixture with acetonitrile and methanol, since acetonitrile is an expensive solvent. Moreover, what these studies have in common is the use of type $\mathrm{C}_{18}$ columns, which, according to Sinha et al. (16), using columns of this type retains more polar compounds. Thus, both mobile phases in this study were acidified with glacial acetic acid, which increased the peak resolution vanillin compared with trifluoroacetic acid and phosphoric acid, and the column used was of type $\mathrm{C}_{18}$, to support the $\mathrm{pH}$ range of the selected mobile phase, resulting in better peak resolution. After reading the wavelength determined by scanning (190-400 nm), it was adjusted to $280 \mathrm{~nm}$. Subject to the conditions, vanillin showed an average retention time of approximately 13.0 minutes. The chromatograms obtained for vanillin, herbal material and tincture are shown in (Figure 3). 


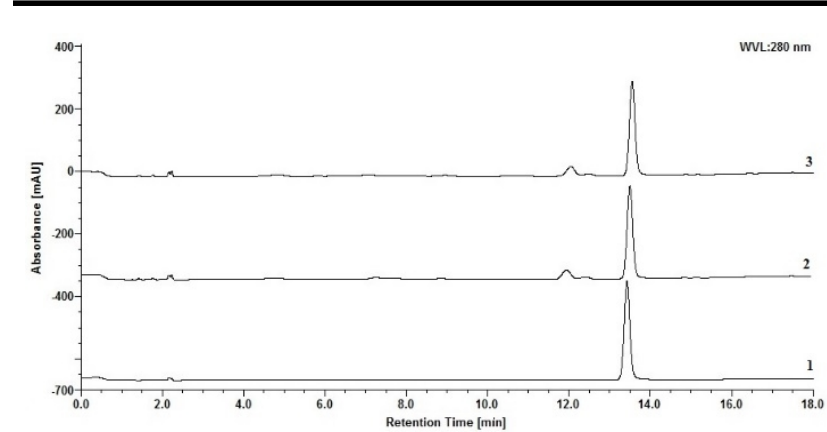

Figure 3 Chromatogram obtained by HPLC-PDA for herbal material (1), tincture (2) from pods of $V$. planifolia and the standard - vanillin (3).

\section{Method validation}

The system suitability test involves the check of limits for chromatographic parameters to prove that the data and system are adequate for the analysis and can be submitted to regulatory agencies. The values obtained for the analysis of standard vanillin was: $\mathrm{Rs}=2.8 ; \mathrm{RSD}=0.37 ; \mathrm{k}^{\prime}=2.7 ; \mathrm{T}$ $=0.81$; and $\mathrm{N}=11177$. The results found for this system demonstrating good criteria of acceptance.

The linearity of the method was confirmed using calibration curves of the standard (vanillin), herbal material and tincture at five concentration levels. The results of the calibration curves showed good linear correlation between the values of the area and determined concentration, with $R^{2}$ values $>$ 0.99. According to regression analysis curves of the standard, herbal material and vanilla tincture there was no lack of fit. The LOD and LOQ were calculated according to the equations indicated and the analytical method showed good sensitivity for quantification of vanillin in herbal material and tincture of $V$. planifolia pods (Table 3 ).

Table 3 Calibration data for the equations performed from standard solution (Vanillin), the pods (herbal material) and tincture from $V$. planifolia.

\begin{tabular}{lcccc}
\hline & Vanillin & $\begin{array}{c}\text { Herbal } \\
\text { Material }\end{array}$ & Tincture \\
\hline Concentration & range & $32-48$ & $1600-$ & $1600-$ \\
$(\boldsymbol{\mu g} / \mathbf{m L})$ & & - & 1.6822 & 2400 \\
$\mathbf{L O D}(\boldsymbol{\mu g} / \mathbf{m L})$ & - & 5.6074 & 9.5258 \\
LOQ $(\boldsymbol{\mu g} / \mathbf{m L})$ & 1.5389 & 0.0221 & 0.0254 \\
Angular coefficient (a) & 12.8770 & 4.3815 & 0.7218 \\
Linear coefficient (b) & 0.9919 & 0.9980 & 0.9986 \\
$\boldsymbol{R}^{2}$ & & & \\
\hline
\end{tabular}

Precision was assessed by evaluating the average content and relative standard deviation obtained for the analysis. The repeatability gave an average vanillin content equal to $1.82 \mathrm{~g} \%(0.63)$ in the herbal material and $0.21 \mathrm{~g} \%(0.90)$ in tincture. The intermediate precision gave an average content of vanillin of $1.84 \mathrm{~g} \%$ (1.13) compared to day one and 1.83 $\mathrm{g} \%(0.51)$ on the second day with the herbal material; and $0.21 \mathrm{~g} \%(0.29)$ of vanillin, on both days, in regard to the tincture. The low relative standard deviation ( $\mathrm{RSD} \%)$ in the assays demonstrated that the method was precise (Table 4), in accordance with current legislation $(20,21)$.
For the accuracy of the method evaluated by recovery, vanillin solutions which were added with known concentrations of the solutions of the herbal material and tincture of vanilla $(2000 \mu \mathrm{g} / \mathrm{mL})$, presented recoveries between 93.12 and $94.02 \%$ with an average of $93.48 \% \pm$ $12.54(0.58)$ in respect to herbal material; and between 101.01 and $113.74 \%$, with a mean of $105.98 \% \pm 0.03(0.04)$ for tincture. The results show that the developed method has a satisfactory accuracy in respect to complex samples (80$120 \%$ ).

Table 4 Repeatability, Intermediate precision and Interlaboratorial Reproducibility tests: total of vanillin content $(\mathrm{g} \%)$ for the pods (herbal material) and tincture from $V$. planifolia.

\begin{tabular}{|c|c|c|c|}
\hline Material & Parameters & $\begin{array}{r}\text { Content } \\
\text { SD; }\end{array}$ & $\begin{array}{l}\text { (Mean } \pm \\
\%)\end{array}$ \\
\hline \multirow{8}{*}{$\begin{array}{l}\text { Herbal } \\
\text { Material }\end{array}$} & Repeatability & \multicolumn{2}{|c|}{$1.82 \pm 0.0115(0.63)$} \\
\hline & $\begin{array}{l}\text { Intermediate } \\
\text { precision }\end{array}$ & Day 1 & Day 2 \\
\hline & \multirow[b]{3}{*}{ Analyst 1} & $1.82 \pm$ & $1.83 \pm$ \\
\hline & & 0.0112 & 0.0014 \\
\hline & & $(0.61)$ & $(0.08)$ \\
\hline & \multirow[b]{3}{*}{ Analyst 2} & $1.85 \pm$ & $1.82 \pm$ \\
\hline & & 0.0203 & 0.0142 \\
\hline & & $(1.09)$ & $(0.78)$ \\
\hline \multirow{8}{*}{ Tincture } & Repeatability & \multicolumn{2}{|c|}{$0.21 \pm 0.019(0.90)$} \\
\hline & $\begin{array}{l}\text { Intermediate } \\
\text { precision }\end{array}$ & Day 1 & Day 2 \\
\hline & \multirow[b]{3}{*}{ Analyst 1} & $0.21 \pm$ & $0.21 \pm$ \\
\hline & & 0.0005 & 0.0005 \\
\hline & & $(0.25)$ & $(0.24)$ \\
\hline & \multirow[b]{3}{*}{ Analyst 2} & $0.21 \pm$ & $0.21 \pm$ \\
\hline & & 0.0008 & 0.0002 \\
\hline & & $(0.38)$ & $(0.11)$ \\
\hline
\end{tabular}

SD: Standard Deviation; RSD\%: Relative Standard Deviation.

The robustness should be evaluated during the development of the HPLC-PDA method by performing small changes in the original method, since in chromatographic methods, among other aspects, the $\mathrm{pH}$ of the mobile phase, flow rate, and column temperature can be altered. In this sense, the method can be considered robust for the three parameters that have been modified and the results are shown in Table 5 . There were no differences in the area and the retention time of vanillin, with $\mathrm{RSD}<5 \%$. 
Table 5 Robustness: retention time $\left(\mathrm{R}_{\mathrm{t}}\right)$ and total vanillin content ( $\mathrm{g} \%$ ) for the pods (herbal material) and tincture from $V$. planifolia.

\begin{tabular}{|c|c|c|c|c|}
\hline & $\begin{array}{l}\text { Source of } \\
\text { variation }\end{array}$ & Parameters & $\begin{array}{c}\mathbf{R}_{\mathbf{t}} \text { of } \\
\text { Vanillin } \\
\text { (Mean; } \\
\text { RSD\%) }\end{array}$ & $\begin{array}{c}\text { g\% } \\
\text { (Mean; } \\
\text { RSD } \\
\% \text { ) }\end{array}$ \\
\hline \multirow{6}{*}{$\begin{array}{l}\text { Herbal } \\
\text { material }\end{array}$} & \multirow{2}{*}{$\begin{array}{l}\text { Flow rate }(\mathrm{mL} / \\
\mathrm{min})\end{array}$} & 0.900 & $\begin{array}{l}13.57 \\
(0.48)\end{array}$ & $\begin{array}{c}1.83 \\
(0.18)\end{array}$ \\
\hline & & 1.100 & $\begin{array}{l}13.48 \\
(0.25)\end{array}$ & $\begin{array}{c}1.83 \\
(0.36)\end{array}$ \\
\hline & \multirow{2}{*}{$\begin{array}{l}\mathrm{pH} \text { of mobile } \\
\text { phase }\end{array}$} & $\begin{array}{c}\text { A } 2.0-\mathrm{B} \\
3.0\end{array}$ & $\begin{array}{l}13.25 \\
(1.56)\end{array}$ & $\begin{array}{c}1.83 \\
(0.29)\end{array}$ \\
\hline & & $\begin{array}{c}\text { A } 3.0-\mathrm{B} \\
4.0\end{array}$ & $\begin{array}{l}13.37 \\
(0.11)\end{array}$ & $\begin{array}{c}1.84 \\
(0.40)\end{array}$ \\
\hline & \multirow{2}{*}{$\begin{array}{l}\text { Column } \\
\text { temperature } \\
\left({ }^{\circ} \mathrm{C}\right)\end{array}$} & 23 & $\begin{array}{l}13.24 \\
(1.34) \\
\end{array}$ & $\begin{array}{c}1.82 \\
(0.37)\end{array}$ \\
\hline & & 25 & $\begin{array}{l}13.27 \\
(1.43) \\
\end{array}$ & $\begin{array}{c}1.83 \\
(0.04) \\
\end{array}$ \\
\hline \multirow{6}{*}{ Tincture } & \multirow{2}{*}{$\begin{array}{l}\text { Flow rate }(\mathrm{mL} / \\
\text { min) }\end{array}$} & 0.900 & $\begin{array}{r}13.49 \\
(0.14) \\
\end{array}$ & $\begin{array}{c}0.23 \\
(0.21) \\
\end{array}$ \\
\hline & & 1.100 & $\begin{array}{l}13.52 \\
(0.05)\end{array}$ & $\begin{array}{c}0.21 \\
(0.61)\end{array}$ \\
\hline & \multirow{2}{*}{$\begin{array}{l}\mathrm{pH} \text { of mobile } \\
\text { phase }\end{array}$} & $\begin{array}{c}\text { A } 2.0-\mathrm{B} \\
3.0\end{array}$ & $\begin{array}{l}13.13 \\
(0.24)\end{array}$ & $\begin{array}{c}0.21 \\
(1.20)\end{array}$ \\
\hline & & $\begin{array}{c}\text { A } 3.0-\mathrm{B} \\
4.0\end{array}$ & $\begin{array}{l}13.19 \\
(1.39)\end{array}$ & $\begin{array}{c}0.21 \\
(0.36)\end{array}$ \\
\hline & \multirow{2}{*}{$\begin{array}{l}\text { Column } \\
\text { temperature } \\
\left({ }^{\circ} \mathrm{C}\right)\end{array}$} & 23 & $\begin{array}{r}13.90 \\
(0.04) \\
\end{array}$ & $\begin{array}{c}0.21 \\
(4.33)\end{array}$ \\
\hline & & 25 & $\begin{array}{l}13.92 \\
(0.04)\end{array}$ & $\begin{array}{c}0.20 \\
(1.19)\end{array}$ \\
\hline
\end{tabular}

The values were plotted with Mean (Relative Standard Deviation $-\mathrm{RSD} \%)$.

\section{Conclusions}

Despite the complexity of presenting vegetable matrices, with the analysis of the parameters evaluated by TLC and HPLC-PDA the development and validation of the method for quantification of vanillin in herbal material and tincture of Vanilla planifolia showed suitability of the methodology for the parameters established by the current international guidelines, and can clearly be used in quality control of herbal material and tincture of this specie.

\section{Acknowledgments}

The authors thank the CNPq (308386/2015-9), FACEPE (APQ-0493-4.03/14) and ANVISA/MS (TC03/2010), for their financial support. The authors are also grateful to Andrew Alastair Cumming for editing this paper.

\section{Conflict of interest}

The authors declare no conflict of interest.

\section{References}

1. Barros F, Vinhos, V.T. Rodrigues, et al., "Orchidaceae in: Lista de espécies da flora do Brasil”. Avaliable at: (http://floradobrasil.jbrj.gov.br/jabot/floradobrasil/FB38 421).
2. Bory S, Lubinsky P, Risterucci AM, Noyer JL, Grisoni M, Duval MF, et al. Patterns of introduction and diversification of Vanilla planifolia (Orchidaceae) in Reunion Island (Indian Ocean). Am J Bot. 2008;95: $805-$

815.

3. Lubinsky P. Origins and dispersal of cultivated Vanilla (Vanilla planifolia Jacks. [Orchidaceae]). Econ Bot. 2008;62:

$127-138$

4. Gleason-Allured J. The state of Vanilla: challenges and opportunities. Perfum Flavor. 2009;34: 19-22.

5. Palama TL, Fock I, Choi YH, Verpoorte R, Kodja H. Biological variation of Vanilla planifolia leaf metabolome. Phytochemistry. 2010;71: 567-573.

6. Bythrow JD. Vanilla as a Medicinal Plant. Seminars in Integrative Medicine. 2005;3: 129-131.

7. Bettazzi F, Palchetti I, Sisalli S, Mascini M. A disposable electrochemical sensor for vanillin detection. Anal Chim Acta. 2006;555: 134-138.

8. Al-Naqeb G, Ismail M, Bagalkotkar G, Adamu HA. Vanillin rich fraction regulates LDLR and HMGCR gene expression in HepG2 cells. Food Res Intern. 2010;43:2437-2443.

9. Perez-Silva A, Gunata Z, Lepoutre J-P, Odoux E. New insight on the genesis and fate of odor-active compounds in vanilla pods (Vanilla planifolia G. Jackson) during traditional curing. Food Res Int. 2011;44: 2930-2937.

10. Lavine BK, Corona DT, Perera UDNT. Analysis of vanilla extract by reversed phase liquid chromatography using water rich mobile phases. Microchem J. 2012;103: 49-61.

11. AOAC. Official Methods of Analysis of the Association of Official Analytical Chemists", in "Association of Official Analytical Chemists. Arlington; 1990. p. 890896.

12. Sharma UK, Sharma N, Gupta AP, Kumar N, Sinha AK. RP-HPTLC densitometric determination and validation of vanillin and related phenolic compounds in accelerated solvent extract of Vanilla planifolia. J Sep Sci. 2007;30: 3174-3180.

13. Sostaric T, Boyce MC, Spickett EE. Analysis of the volatile components in vanilla extracts and flavorings by solid-phase microextraction and gaschromatography. J Agr Food Chem. 2000;48: 5802-5807. 
14. Boyce MC, Haddad PR, Sostaric T. Determination of flavour components in natural vanilla extracts and synthetic flavourings by mixed micellar electrokinetic capillary chromatography. Anal Chim Acta. 2003;485: 179-186.

15. Pyell U, Pletsch-Viehmann B, Ramus U. Component analysis of vanilla extracts and vanilla containing commercial preparations by micellarelectrokinetic chromatography or high-performance liquid chromatography - A method comparison. J Sep Sci. 2002;25: 1035-1042.

16. Sinha AK, Verma SC, Sharma UK. Development and validation of an RP-HPLC method for quantitative determination of vanillin and related phenolic compounds in Vanilla planifolia. J Sep Sci. 2007;30: 1520 .

17. Waliszewski KN, Pardio VT, Ovando SL. A simple and rapid HPLC technique for vanillin determination in alcohol extract. Food Chem. 2007;101: 1059-1062.

18. Brazilian Pharmacopoeia. 5th ed. Brasília: Anvisa; 2010.

19. Myers RH, Montgomery DC. Response Surface Methodology. 1th ed. New York: Willey; 1995.

20. ICH. Validation of Analytical Procedures: Text and Methodology Q2 (R1) in International Conference on Harmonisation of Technical Requirements for Registration of Pharmaceuticals for Human Use. Geneva;
21. Brazil. Agência Nacional de Vigilância Sanitária; Guia para Validação de Métodos Analíticos e Bioanalíticos, Resolução - RDC no 166, de 24 de julho de 2017.

22. Center for Drug Evaluation and Research, U.S. Food and Drug Administration. Reviewer Guidance, Validation of Chromatographic Methods; FDA, Rockville, $\quad$ MD; $\quad$ Nov 1994.

23. Sharma UK, Sharma N, Sinha AK, Kumar N, Gupta AP. Ultrafast UPLC-ESI-MS and HPLC with monolithic column for determination of principal flavor compounds in vanilla pods. J Sep Sci. 2009;32: 34253431 .

24. Dong Z, Gu F, Xu F, Wang Q. Comparison of four kinds of extraction techniques and kinetics of microwave-assisted extraction of vanillin from Vanilla planifolia Andrews. Food Chem. 2014;149: 54-61.

25. Scharrer A, Mosandi A. Reinvestigation of vanillin contents and component rations of vanilla extracts using high-performance liquid chromatography and gas chromatography. Deutsche Lebensmittel-Rundschau. 2001; 97: 449-456.

26. Herrmann A, Stockli M. Rapid control of vanillacontaining products using high-performance liquid chromatography. J Chromatog A. 1982;246: 313-316. 